The Appearance of Women's Politics in the Correspondence Pages of Aberdeen Newspapers 1900-14

\title{
SARAH PEDERSEN
}

$\underline{\text { Robert Gordon University, Aberdeen, Scotland, United Kingdom }}$

\begin{abstract}
A newspaper's 'Letters to the Editor' column represents its readership in an unique way and can provide a useful 'thermometer' with which to measure the extent of critical debate and discussion a particular issue generated in a locality. In this article, the letters of women to the editor of the Aberdeen Daily Journal, 1900 to 1914 , are analysed to discover the type of political issues with which these women concerned themselves. It is argued that the women must have felt particularly strongly about such issues since they were prepared to take their arguments outside their social circle and to identify themselves as politically active in the pages of their daily newspaper. Political issues dealt with include local government, the suffrage question and government legislation. While much of the evidence used comes from the letters of active suffragists who were usually members of national suffrage associations, it is argued that the period showed an expansion in the type of woman interested in politics, and the corresponding urge to write to the newspapers. This is evidenced in the number of women who firmly stated that they were not suffragists, but became politicised enough to write to the newspaper complaining about the Insurance Act in 1912.
\end{abstract}


The following is based on a study of the letters of women correspondents to the Aberdeen Daily Journal between 1900 and the outbreak of war in 1914. It assesses the letter-writers' attitudes to contemporary political issues, whether local, national or those perceived as 'women's issues', in particular women's involvement in local politics and the suffrage question. The majority of women correspondents on these issues tend to be examples of the 'New Woman'-keen to be involved as much as possible in politics and eager to share their opinions with men and women outside their immediate circle. However, this research has also identified a different kind of woman emerging, perhaps more reluctantly, during this period to deal with what was perceived as a governmental attack on the 'woman's sphere'. As will be shown later, some good examples of this kind of correspondence occurred in response to the Health Insurance Bill of 1911, when women usually hostile to woman suffrage and all that the name 'suffragette' implied, and reluctant to get involved in political debate, committed themselves in print to a political debate which they felt impacted directly on their homes.

The Aberdeen Daily Journal, established in 1748, is one of the oldest daily newspapers in Europe. Even today, the newspaper, which refers to itself as 'The Voice of the North', is regarded as representing a well-defined geographical area, recognised in cultural, social and political terms - and such was definitely the case 100 years ago. This makes it an ideal tool for the investigation of Scottish provincial attitudes to London-based events, or to national issues where the agenda appears to have been dictated from London or Edinburgh, in particular the policies of the various women's suffrage societies. 
The period in question was a time of growth for the Journal, with its circulation improving steadily from a low of under 10,000 in 1886 to 29,760 at the outbreak of World War I.[i] This period saw three editors-David Pressly (1894-1903), Robert Anderson (1903-1910) and William Maxwell (1910-1927)—all of whom were concerned with establishing the conservative Journal as the pre-eminent newspaper in north-east Scotland, in particular in the face of strong competition from the more liberal Aberdeen Free Post. The later editor, William Maxwell, was an especially strong Unionist, who aimed at converting the fundamentally liberal North-East to Unionism - in later life he became the President of the South Aberdeen Unionist Association.[ii] He also desired to make the Journal the national Scottish newspaper, and so went into competition with the Scotsman and the Glasgow Herald. This desire to develop a provincial newspaper into a national newspaper meant more coverage of national news (both Scottish and British), building on the innovation of David Pressly, who had had a private wire to the firm's London offices installed in order to improve the flow of news and commentary from London.[iii]

Letters to the editors of newspapers are - and were in the early 20th centuryan everyday occurrence, and represent the voice of the readership of such newpapers in an unique way. It has been suggested, for example by commentators such as Foster and Friedrich, that letters to the editor of a newspaper can provide us with a useful 'thermometer' with which to measure the amount of 'heat'-in terms of critical debate and discussion - a particular issue aroused in the locality.[iv] Research into contemporary letter-writers has also led to the suggestion that letters to an editor can be seen as a kind of 'safety valve', allowing angry or upset readers to 'get something off their chest' in a harmless but therapeutic way.[v] 
A letter to a local, or national, newspaper was one way in which a woman of the early twentieth century could make her political opinions known to people outside her social circle. She could assume that both men and women in a comparatively wide geographical area would read, and either agree or disagree with, her letter. The letters from women which appear in the Aberdeen Daily Journal are both from highly politicised women who have ventured into the public sphere in other ways (such as political meetings, local government, suffrage bodies or charitable associations) and from other, more anonymous women, writing on a subject that has particularly vexed them. For many of these women, the one or two letters printed in a local newspaper may be the only printed inheritance we have of them. Hence, for a local study looking at women's attitudes to the political issues of the time, letters to the editor offer an unique source, allowing understanding of grassroots opinion.

The Aberdeen Daily Journal is also useful for this study since it shows no evidence of what has been called 'editorial gatekeeping'. Many contemporary studies of newspaper correspondence have found it difficult to assess the representativeness of letters published in newspapers because of an element of editorial choice or censorship, meaning that some letters are not published. Such censorship is implemented because of a lack of space or in an attempt to remain strictly politically neutral.[vi]

No material evidence of such editorial gatekeeping has been found in the Aberdeen Daily Journal during the period 1900-14. The policy appears to have been one of full publication of all letters, as long as they were accompanied by a name and address (although correspondents could request their identity to remain anonymous when the letter was printed). When the editor did decide not to print a 
letter, a note appeared at the bottom of the Letters column, giving a reason. For example, on 13 January 1914, the editor (William Maxwell) noted: "To Miss O. Walton and Miss Agnes Kelly_-As the case was, in harmony with public sentiment, conducted in private, and as no point of public interest is raised anew, correspondence of this kind will serve no good purpose."[vii] Olive Walton was the WSPU organiser in Dundee at this time, and a Miss Walton is mentioned by the newspaper in March 1912 as presiding at a meeting of the Women's Social and Political Union in Aberdeen's Union Street, so it is probable that her letter touched on some aspect of women's politics. However, since no record of unpublished letters survives, this is impossible to confirm.

It might be suggested that editorial gatekeeping on a large scale is a more modern phenomenon. Anita Sama states that she found no evidence of it in her investigation of The Times and the women's suffrage movement 1900-18. Indeed, she suggests that women were able to use letters to the editor to get their demands and arguments printed in an anti-suffrage paper run by an anti-suffrage editor since The Times had a policy of fairness throughout and published letters from both sides.[viii] In addition, in his study of the Los Angeles Times 1881-89, Ralph E. Shaffer reports little evidence of editor H. G. Otis deliberately suppressing letters stating a position he did not like. Thus, Otis ran many letters that were pro-union, despite his anti-union feelings, although occasionally adding a postscript, in opposition to the author's viewpoint.[ix] The editor of the Aberdeen Journal also used postscripts to put across his opposing viewpoint. For example, on 30 July 1912, Helen Tollie, Aberdeen WSPU Organiser, had a letter printed on the subject of 'Suffragettes and Equality'. The editor followed this with a postscript stating: "That 
women can never be similar to men is obvious, and when Suffragettes, or women generally, try to compete with men on their own ground they are not only unequal, but, as a rule, they become mere imitations of third-rate men-The Editor" (again, the Unionist William Maxwell).[x]

My research involved analysing the content of every letter sent to the Journal by correspondents identifying themselves as women. Not all correspondents chose to have their names and addresses printed with their letters, which does introduce the problem of identifying female correspondents. I decided to identify as a woman only correspondents giving their full name, using a female nom de plume or identifying themselves as female in their letters. Many nom de plumes used in the correspondence columns of the newspapers were gender-specific, 'A Working Man', 'Dorcas' or_very popular_ 'A Mother'. Others, such as 'Suffra Jet' or 'Member of the WSPU' also imply a female correspondent. It has to be accepted that some female correspondents were not identified using these criteria. It is impossible to discern the gender of 'Hopeful' or 'Annoyed of Crathes'. Someone using a nongender-specific name obviously did not want to be identified as a woman — and was presumed by any subsequent correspondents to be male. Identifying such correspondents as non-female did not affect the overall findings of this research, which was concerned only with correspondents who wished to be identified as female. Correspondents who signed themselves with initials or A. B. Smith etc. were also counted as non-female, again using subsequent correspondents' assumptions that they were male ('Mr Smith's letter of ...').

The letters in the sample cover a wide variety of subjects, some of which might be identified as belonging to a supposed 'women's or domestic sphere', such as the 
issue of butter-making and bad butter, which crops up throughout the period with depressing regularity. Other topics, however, are not so gender-specific, such as the appointment of a new Bishop of Aberdeen and Orkney, or comments on the latest gruesome murder. The letters this research concentrates on are those that might be described in some way as 'political'. If we take this group to include letters on parish councils, school board elections, government legislation, MPs and political parties, as well as the issue of women's suffrage and equality of opportunity, there is a total of 90 letters from the period in question. This is out of a total of 407 letters to the editor identified as being written by women and published in the Aberdeen Journal between 1900 and 1914. Of these ninety letters, sixty-six give the correspondent's full name, and usually some form of address, while only twentyfour hide behind a nom de plume. The large number of signed letters helps refute any suggestion of the fabrication of letters by the editor and his staff since the majority of the women thus named are identifiable as active in Aberdeen or the surrounding county or members of well-known families in the area.

While it might have been expected that there would be much correspondence on local government matters from women, there are only eight letters on these matters in the sample. There is evidence of early concern that women needed to put themselves forward for election, although an overall unwillingness among correspondents to stand themselves. In October 1901 Agnes Bruce urged that "our sex ought to have adequate representation on local boards" and called for a lady "public-spirited enough to consent to be nominated". The reasons she put forward for this need were that there was a large proportion of women ratepayers who ought to be represented by one of their own sex, and the nature of the work of parish 
councillors. "A great deal of the practical knowledge and shrewdness that come to a woman who has had to make the best of a small sum would be very useful there."[xi]

In 1901, there was a perception of the need for some sort—perhaps any sort—of female representation on public bodies because of women's peculiar virtues. By 1909, however, perhaps after more experience of women office-holders, the quality and background of prospective candidates had become more important. Although two women had put themselves forward for election to the School Board in March 1909, a letter from Jean Coutts questioned their motivation:

There is a point which neither lady has yet made clear to the electors. I am tempted to ask if the principle of the representation of women is their only object in coming forward ... I ask these questions because it would be extremely undesirable ... that at present the two ladies mentioned, who are practically unknown in the public life of the city, should even be considered seriously as candidates without these points being clearly understood.[xii]

Was this perhaps evidence of a backlash against women candidates because of the activities of the suffragettes?

Usefully, the sample contains three letters from a serving female member of the city parish council. Mrs Susan Murray wrote her first letter in 1903 as a parish councillor elected by the St Nicholas Ward. There are two other letters from her in autumn 1904, objecting to the smearing of her name during the council electionswhich she lost: 
I see that Mr William Robertson, at the Rubislaw Ward meeting last night, said that "The three ladies who had sat on the board were useless, and whenever the chairman and his friend Mr Macphail proposed a thing, these ladies were to be found supporting them"... Speaking for myself, this is not the case. I always voted according to my own convictions, which were often in opposition to the views of the chairman and his party, tending too often to my discomfort on the board.[xiii]

She, too, felt that she was peculiarly qualified as a woman to act as councillor through her varied experience amongst the poorer classes for thirty years, and stated in a letter on 26 October 1904 that she had told the ward committee that she would not consider standing down unless another woman came forward to take her place.[xiv] However, Mrs Murray may not have been the dedicated councillor she claimed to be. Two of her three letters apologise to the ward electors for her nonattendance at meetings and she even admitted that, "Living at a distance, and for other reasons, I am in ignorance of what is going on amongst the councillors."'[xv] An interesting admission that may have adversely affected the cause of women's political representation in Aberdeen!

The vast majority of letters from women on political topics focus on women's suffrage. There are forty letters from Aberdeenshire women; sixteen from women outside Aberdeenshire, and only five explicitly anti-suffrage women correspondents. It has been noted that women who were prepared to identify themselves as women were overwhelmingly pro-suffrage. Those who wrote anti-suffrage letters were 
either male correspondents or chose not to identify their gender. However, it is difficult to draw any definite conclusions from this about women readers' overall opinion of suffrage, since it may well be that anti-suffrage women were more anxious about identifying themselves, to both the general public and to suffragists. Certainly, in 1909, one correspondent stated at the end of her letter criticising those who were campaigning for the suffrage: "The policeman who passes peaceably along my street wouldn't like to be scratched, and I should not like my window smashed. So ... I sink my personality beneath a safe anonymity, and subscribe myself Madame X.”[xvi]

Scotland, and Aberdeenshire, figured prominently in the suffrage campaign of these years. For a full survey of women's suffrage in Scotland, Leah Leneman's The Guid Cause: The Women's Suffrage Movement in Scotland offers an excellent starting point.[xvii] For the purposes of this article, it needs to be noted that Scotland as a whole, and Aberdeenshire in particular, was Liberal country, with many prominent members of the government, including Prime Minister Asquith, holding Scottish seats. Many of the women leading the campaign for suffrage in Aberdeenshire were also important members of the local Liberal Association, which meant divided loyalties, particularly after the advent of the WSPU. However, as Leneman's book points out, at a local level in Scotland, members of the NUWSS, WSPU and Women's Freedom League (WFL) plus the Liberal Party might cooperate, and even overlap, particularly in the early years of the WSPU's campaign.[xviii]

The letters to the editor from outside Aberdeenshire are mainly from the headquarters of the various societies in London and Edinburgh, and are notable in 
this context only for the light they throw on the societies' relationship with the provincial press. Most of the letters seem to be standard press releases, explaining the aims of the society or calling for participation at marches and demonstrations, with no reference to the particular town in which the newspaper is published. Some of the letter-writers did attempt to personalise their form letter slightly. A letter from Helen Fraser, at that time organiser of the Scottish NUWSS, starts: "I shall be exceedingly obliged if you will grant me space in your columns to explain the policy and method of working the NUWSS, of which the Aberdeen Association for Women's Suffrage is the local branch.'[xix] No other mention of Aberdeen is made throughout her letter and the insertion of the name of the local branch was probably made to make the letter more relevant to the intended readership.

Some letters were, however, sent from the suffrage societies in direct response to articles or other letters in the Journal. This again highlights the fact that the letters were not fabricated to create discussion - in fact the majority of letters studied here were responses to previous correspondence. In October 1913, E. C. Philips of the NUWSS in London wrote a letter in response to a male correspondent's epistle on 'Man, Woman and the Vote', while Muriel Scott of the Edinburgh branch of the WSPU responded immediately to a letter from Mr Cowan, a local MP, attacking a speech she had made earlier that summer.[xx] Letters such as these suggest that either the local Aberdeen branches were acting as cuttings agencies for their headquarters or the Journal was deemed an important enough newspaper for the headquarters to subscribe in order to keep informed about North of Scotland opinion. 
More interesting from the point of view of the provincial historian are the letters submitted by local women on the subject of women's suffrage, which give an insight into the relations between the various suffrage and other political societies at grassroots level. A persistent letter-writer and supporter of women's rights in the wider context was Mrs Marian S. Farquharson, member of the Women's Local Government Society, the Women's Progressive Union and President of the Scottish Association for the Promotion of Women's Public Work. Always with an opinion on whatever subject was being debated in the letters columns, apparently whether she knew much about the subject or not (her comments on butter-making were scorned by a succession of farmers' wives and daughters), Mrs Farquharson was most keen on the promotion of women's public work. Letters from her are frequent in the first half of the period, and it may be that she felt that the rising interest in the issue of women's suffrage stemming from suffragette activities hampered or restricted her wider agenda. Certainly, in June 1909, she wrote:

While so much public attention has of late been drawn to the agitation for votes for women, it is well, I think, that the long-continued and still active movement for the educational progress of women, for the securing for them equal opportunities of competition in the race of late with men, and for obtaining the removal of the various legal disabilities affecting them by reason of their sex, should not be lost sight of. ... It is therefore gratifying to the army of quiet and persistent women workers, aided by powerful supporters of the other sex, to realise that their efforts have been widely appreciated, and in many directions 
crowned with success in moulding public opinion without resorting to any adventitious or 'militant' methods.[xxi]

As has been mentioned, the suffrage societies were in competition with the local parliamentary political parties for women's support, time and money; and relations between the Liberal Party and suffrage societies in Aberdeenshire were particularly complex, North-East Scotland being a Liberal stronghold. Many members of the older Women's Suffrage Society (affiliated to the NUWSS) were also Liberal supporters. As Isabella Fyvie Mayo of the WSPU put it in February 1907:

I may remark that the older 'Aberdeen Women's Suffrage Society' has seemed to many, even of its own members - of whom I have never been one- to be singularly effete in its operations. The Society can easily defend itself from this charge by giving a detailed record with names and dates - of any active protest or propaganda in which it has engaged, say, during the last seven years. Its executive, too, is so entangled with that of the Aberdeen Women's Liberal Association as to limit its movement, practically, to women of one shade of political opinion.[xxii]

Isabella Fyvie Mayo, the writer, had been the first woman to be elected to a public board in Aberdeen. The above letter was written during the controversies of the South Aberdeen by-election of 1907, which brought with it Aberdeen's first taste of WSPU 'tactics'. Leaders of the WSPU, including Mrs Pankhurst, Helen Fraser and Teresa Billington-Greig, arrived in the city to set up a branch of the WSPU and held 
a series of meetings, some of which were chaired by Isabella Fyvie Mayo. One of the meetings was marred by a platform disagreement about the precise nature of the WSPU demands (Mrs Pankhurst disagreeing with—and over-ruling-Mrs Mayo). In her analysis of suffrage tactics during this by-election campaign, which makes wide use of newspaper accounts and correspondence, Lindy Moore suggests that Isabella Fyvie Mayo's attack on the Aberdeen Women's Suffrage Society was an attempt to defend her support for the WSPU and to turn the press spotlight away from any internal disputes by attacking the record of the existing women's suffrage society.[xxiii] She may also have been hoping to encourage recruits for the newlyformed Aberdeen WSPU branch from the older suffrage society or the Liberal Association; large numbers of members of both associations were reported by the Journal to have attended WSPU meetings during the by-election campaign.

There is evidence in the letters columns of continued pressure being brought to bear on the local Women's Liberal Association to campaign for local MPs' support for women's suffrage. By November 1907 Caroline Philips, honorary secretary of the Aberdeen WSPU, evidently felt that this pressure was beginning to work, claiming that 'It is refreshing to the 'suffragette' mind to realise that the leaven of the influence of the 'Suffragettes' is evidently beginning to permeate the ranks of the Aberdeen Women's Liberal Association.”[xxiv]

Such unanimity was not to last very long, and did not include all women supporters of the Liberal party. In late December of the same year the Chancellor of the Exchequer, Lloyd George, visited Aberdeen and held a Liberal party meeting in the Music Hall. Mrs Pankhurst was amongst those who attended, but-evidence of some co-operation at a local level — it had been agreed by the WSPU that Asquith 
would be given an uninterrupted hearing if Mrs Black, the President of the Women's Liberal Association, would put one question to him regarding woman suffrage. In the event, she had difficulty posing her question and was told that she was out of order.[xxv] However, the main protagonist in disrupting the meeting was an elderly local minister, Alexander Webster. An infuriated correspondent, describing herself as a Woman Liberal, wrote the next day:

I was deeply grieved to see the unseemly struggle in the orchestra, particularly as the individual concerned was an old man, and, had I been near, I should at once have gone to his assistance. I must confess, however, that, while standing on Union Street after the meeting, this kindly feeling received rather a rude shock, when who should pass, looking quite trim, alert and happy, but our friend Mr Webster, hand in glove with the Suffragists. Again, when passing Broad Street, a little later, there was he laying off with great gusto to his female admirers. "This lets the cat out of the bag", thought I derisively ... It was perfectly obvious to any observant eye that the bulk of the audience really enjoyed the Suffragist affair — and assuredly the ladies (?) themselves did. Their conduct, I am sorry to say, was by no means lady-like; but these tactics seem to pay, thanks to the usual blundering stupidity of the sterner sex. ... The Press, I need hardly say, have greatly magnified the absurd affair. Men again![xxvi]

Relations with the women Liberals soured even more the following year when Teresa Billington-Greig, by then of the Women's Freedom League, visited the city for a by-election campaign. It was reported in the newspapers that a Miss Craigmyle 
of the Women's Liberal Federation had made a violent attack upon the policy and tactics of the militants. Mrs Billington-Greig at once wrote a letter to the Journal challenging Miss Craigmyle to a public debate on the topic. There was no response, and Mrs Billington-Greig wrote once more, offering Miss Craigmyle the possibility of selecting a champion — male or female — and urging her to disassociate herself from the Liberal Federation since " $[\mathrm{t}]$ he protection afforded by anonymous officials, who are chiefly remarkable for bad taste and an inability to give a direct answer to a direct challenge, must leave her in considerable discomfort."[xxvii] Teresa Billington-Greig continued to receive no answer to challenge and eventually left the city, declaring herself the victor.

It is thus seen that the rich vein of newspaper letters columns can inform a study of 'women's politics' at grassroot level and can indicate the type of issues which caused a 'rise in temperature' locally, in terms of the amount of discussion and argument generated. In Aberdeenshire, the issue of whether to put party or suffrage first was evidently one that concerned both women within the Liberal party and those outside the party who were attempting to galvanise support for direct action against the government. The columns of the local newspapers formed a useful battlefield for both sides of the argument, and letters on such topics from members of the suffrage societies and the Liberal association show how national policies and arguments might be adapted for local use. In addition, the letters columns could act as a 'safety valve', giving an opportunity for women such as 'Woman Liberal' to vent their anger about particular issues which annoyed or angered them.

The letters column of the Aberdeen Journal also demonstrates women's increasing involvement in the wider world of politics outside the demand for sexual 
equality. In 1911-12, at the same time that the letters columns of the Journal carried pro- and anti-suffrage letters, one subject mobilised a new group of women to letters of protest - the Insurance Bill. Apart from persistent correspondents like Marian Farquharson, who had tackled subjects such as tariff reform, few women before this date wrote letters to the Journal on 'hard' political subjects apart from those related to the suffrage. The Insurance Bill was to change that.

The Insurance Bill was an attempt by the Liberal Government to introduce a scheme of contributory health insurance for workers and meant that employees and employers were now obliged to contribute payments to a fund set up for this purpose. Whilst there were a few letters to the Journal from employees, worrying about the implications of this new 'tax', as it was seen, the majority of the storm of protest that followed the announcement of the bill came from employers - and, in particular, from women. Upper and middle-class women identified themselves as the 'employer' affected by this bill because they were the ones responsible for paying the servants of the household. Indeed, many of the letters at this time referred to the 'Servant Tax'. 'A Farmer's Wife' wrote in December 1911:

It will not only mean unemployment in towns, but likewise among farm and domestic servants; and especially ... the inefficient class will suffer, as neither master nor mistress will be willing to pay wages and pay insurance, and still have to teach them everything in connection with their work.[xxviii]

What is so interesting about many of the letters from female correspondents objecting to the Insurance Bill is that they wished to make it quite clear that this 
issue alone had stirred their interest in politics and that they were in no way in favour of women receiving the vote. 'Not a Suffragette' wrote in June 1912 to encourage more women to involve themselves in the anti-Insurance Bill cause:

Many women have spare time in which to help. If they are in earnest, let them volunteer themselves for districts wherein to get signatures, not to be paid work, but to be done gratuitously, after the necessary printed forms have been supplied. For myself, I am a businesswoman and have very little spare time, but I would do my share were such a thing set on foot.[xxix]

A branch of the Servant Tax Resisters' Defence Association was formed in Aberdeen and the honorary secretary of the association, Miss Margaret Douglas, travelled from London to address them in October 1912. As she explained in a letter to the Journal, she saw herself as a perfect example of the type of woman pushed into political protest by this bill. In response to an attack by the Rev. Mackie of Drumoak she wrote:

That I am a female, I must admit, but even Mr Mackie must have enough sense of justice to recognise that this is my misfortune, not my fault.

As regards his delightful epithets, I challenge him to produce any speech of mine of the "suffragist firebrand type" and here inform him that until the Insurance Act came into my house and tried to interfere between me and my servant, I have not taken any part in any political work or agitation of any kind. $[\mathrm{xxx}]$ 
While letters such as that from 'Not a Suffragette' and Margaret Douglas made direct denials of any wish for political rights for women, there were a few correspondents who made the connection between lack of the franchise and lack of a voice to complain about such attacks on women's domestic sphere. On 30 November 1911, Euphemia R Cowan pointed out bitterly:

We are told to send our papers of protest against the servant tax to our representatives in Parliament, but we women who are widows or spinsters have no Parliamentary representative, seeing we have no vote.

We are still capable of paying taxes, for which privilege we should be duly thankful, but we are reckoned, I believe, along with imbeciles in connection with voting for members of Parliament.[xxxi]

However, Euphemia Cowan was amongst a minority. Most women correspondents who wrote in protest against the Insurance Act made no connection between their political impotence and their desire that the Government stop 'interfering' in their domestic affairs, despite the fact that their letters were often printed in the same column as letters on the subject of woman suffrage. These women did not come from the traditional, liberal, feminist elite who were happy to contribute their thoughts on political issues to newspapers. They came from the broader section of the female population who had hitherto refrained from political comment. It is possible that, although such women scorned the idea of woman suffrage, the 
ongoing debate by politicised women and about women's politics prompted them to offer their own opinions.

The period shows an incremental growth in women's involvement in political debate and representation, from membership of local school boards and involvement in local government, to a demand for national political representation. By the beginning of the First World War, such politicised women were beginning to be joined by others who protested against the name 'suffragette'. For these women, government initiatives can, perhaps, be seen as a turning point, focusing their attention on overtly political matters. Regardless of their personal views on women's rights, when suddenly confronted by a particular piece of legislation which they felt threatened their domestic peace, they felt able to commit themselves in print to a political debate. Government initiatives such as the Insurance Act can thus be seen as important mobilisers of poltical protest from the 'women's sphere'.

The New Woman was a willing correspondent in the Scottish provincial press on a variety of political subjects, in particular women's suffrage. The correspondence in the Aberdeen Daily Journal 1900-14 offers an insight into the thoughts and ambitions of such women at a local level, both within and without the national suffrage societies (although much more work remains to be done before a complete picture appears, including comparison with the letters sent to the more liberal Aberdeen newspaper, the Free Press). Letters to the editor offered an opportunity for the woman interested in politics to share her opinions with those outside her immediate circle. The Journal's column also offered a space for the various women's political associations and suffrage societies to explain their agenda and argue their case in greater depth than perhaps the other pages of a conservative 
newspaper would afford. In letters columns of local newspapers we are able to identify the issues which caused the most argument and 'heat' in that locality, and see how these issues are influenced by local considerations and are therefore not quite the same as those discussed at national level. 
SARAH PEDERSEN is a Lecturer, and the Course Leader of the postgraduate course in Publishing Studies, in the School of Information and Media, Robert Gordon University, Aberdeen AB10 7QE, UK (s.pedersen@rgu.ac.uk). She has previously worked in educational publishing and is currently working on a study of women correspondents to Aberdeen daily newspapers. 


\section{Notes}

[i] Norman Harper (1997) First Daily, pp. 30-32 (Aberdeen: Aberdeen Journals).

[ii] For more details on the newspaper and its editors at this time, see George Fraser and Ken Peters (1978) The Northern Lights, pp. 46-71 (London: Hamish Hamilton).

[iii] Fraser and Peters, The Northern Lights, p. 47.

[iv] H. Foster Schuyler and Carl J. Friedrich (1972) Letters to the Editor: A Reexamination, Journalism Quarterly, 49, p. 142.

[v] For more on contemporary letter-writers, see E. H. Buell (1975) Eccentrics or gladiators? People who write about politics in letters to the editor, Social Science Quarterly, 56, pp. 440-449; T. J. Volgy et al. (1977) Some of my best friends are letter writers: Eccentrics and gladiators revisited, $\underline{\text { Social Science }}$ Quarterly, 57, pp. 321-327; D. L. Grey and T. B. Brown (1970) Letters to the editor: Hazy reflections of public opinion, Journalism Quarterly, 47, pp. 450$456,471$.

[vi] In 'Letters to the editor: Hazy reflections of public opinion', p. 452, Grey and Brown state: "Editorial policy ... severely restricted the research and challenged the whole concept of letters as valid indicators of political feeling."

[vii]Letters to the Editor, The Aberdeen Daily Journal, 13 January 1914, p. 7.

[viii] Anita Sama (1975) The Times and the Women's Suffrage Movement 19001918. Unpublished Mlitt dissertation, St Andrews. 
[ix] Ralph E. Shaffer (19??) Letters From the People, Los Angeles Times 1881-89, online article at http://www.csupomona.edu/ reshaffer/ accessed September 2000; I am also grateful to Professor Shaffer for discussing this issue in personal correspondence.

[x] Letters to the Editor, Aberdeen Daily Journal, 30 July 1912, p. 3.

[xi] Agnes Bruce, Letters to the Editor, Aberdeen Daily Journal, 17 October 1901, p. 6.

[xii]Jean Coutts, Letters to the Editor, Aberdeen Daily Journal, 15 March 1909, p. 6.

[xiii] Susan Murray, Letters to the Editor, Aberdeen Daily Journal, 26 October 1904, p. 3.

[xiv] Susan Murray, Letters to the Editor, Aberdeen Daily Journal, 26 October 1904, p. 3.

[xv] Susan Murray, Letters to the Editor, Aberdeen Daily Journal, 8 December 1903, p. 7.

[xvi] 'Madame X', Letters to the Editor, Aberdeen Daily Journal, 29 September 1909, p. 7.

[xvii] Leah Leneman (1991) The Guid Cause: The Women's Suffrage Movement in Scotland, (Aberdeen: Aberdeen University Press).

[xviii] For more discussion of the suffrage campaign outside England, see Kirsti Bohata's article in this issue.

[xix] Helen Fraser, Letters to the Editor, Aberdeen Daily Journal, 8 October 1908, p. 3. 
[xx]E. C. Philips, Letters to the Editor, Aberdeen Daily Journal, 8 October 1913, p. 6, and Muriel F. Scott, Letters to the Editor, Aberdeen Daily Journal, 8 September 1911, p. 8.

[xxi] Marian S. Farquharson, Letters to the Editor, Aberdeen Daily Journal, 21 June 1909, p. 3.

[xxii] Isabella Fyvie Mayo, Letters to the Editor, Aberdeen Daily Journal, 11 February 1907, p. 3.

[xxiii] For a much fuller account of the dispute and the whole suffrage campaign during the by-election, see Lindy Moore (1983) The Woman's Suffrage Campaign in the 1907 Aberdeen by-election, Northern Scotland, 5.2, pp. 155178.

[xxiv] Caroline Philips, Letters to the Editor, Aberdeen Daily Journal, 22 November 1907, p. 7.

$[\mathrm{xxv}]$ For more on this incident, see Leneman, A Guid Cause, pp. 54-55.

[xxvi] 'Self-respect', Letters to the Editor, Aberdeen Daily Journal, 23 December 1907, p. 3.

[xxvii] Teresa Billington-Greig, Letters to the Editor, Aberdeen Daily Journal, 27 April 1908, p. 3.

[xxviii]'A Farmer's Wife', Letters to the Editor, Aberdeen Daily Journal, 12 December 1911, p. 3.

[xxix] 'Not a Suffragette', Letters to the Editor, Aberdeen Daily Journal, 28 June 1912, p. 3. 
[xxx] Margaret Douglas, Letters to the Editor, Aberdeen Daily Journal, 28 October 1912, p. 4.

[xxxi] Euphemia R. Cowan, Letters to the Editor, Aberdeen Daily Journal, 30 November 1911, p. 3. 